\title{
Optimization of extraction and identification of volatile compounds from Myrciaria floribunda ${ }^{1}$
}

\section{Otimização da extração e identificação dos compostos voláteis de Myrciaria floribunda}

\author{
Yesenia Mendoza García ${ }^{2}$, Eurico Eduardo Pinto de Lemos ${ }^{2}$, Rodinei Augusti ${ }^{3}$ and Júlio Onésio Ferreira Melo ${ }^{4}$
}

\begin{abstract}
The composition of the volatile profile of rumberry fruits (Myrciaria floribunda) was determined using solidphase microextraction in headspace mode and gas chromatography, coupled with mass spectrometry. The PA (polyacrylate) and DVB/CAR/PDMS (divinylbenzene/carboxen/polydimethylsiloxane) fibers were optimized for the extraction parameters (agitation, extraction time and temperature), in order to select the fiber with the highest number of isolated compounds. A total of 48 volatile compounds were identified using HS-SPME/GC-MS present in the ripe fruits of rumberry. The volatile compounds were classified into five chemical classes, the majority belonging to the sesquiterpenes class ( $71 \%$ ). In addition, it was possible to verify that the fiber coated with polyacrylate (PA) had better performance, allowing for the extraction of a greater number of volatile compounds $(\mathrm{n}=35)$. The extraction conditions that allowed the isolation of a greater number of volatile compounds corresponded to times greater than 26 minutes and temperatures above $85^{\circ} \mathrm{C}$, with agitation of $79 \mathrm{rpm}$ for the PA fiber. Likewise, it was found that the hydrocarbon sesquiterpenes was the chemical class most present in the fruits, which is mainly related to the volatile profile of rumberry fruits.
\end{abstract}

Key words: Rumberry, Myrtaceae, Solid-phase microextraction.

RESUMO - Determinou-se a composição do perfil volátil de frutos de cambuizeiro (Myrciaria floribunda) utilizando-se microextração em fase sólida no modo headspace e cromatografia gasosa acoplada a espectrometria de massas. As fibras PA (polyacrylate) e DVB/CAR/PDMS (divinylbenzene/carboxen/polydimethylsiloxane) foram otimizadas quanto aos parâmetros de extração (agitação, tempo e temperatura de extração), a fim de selecionar a fibra com maior número de compostos isolados. Um total de 48 compostos voláteis foram identificados através do HS-SPME / GC-MS presentes nos frutos maduros de cambuí. Os compostos voláteis foram classificados em cinco classes químicas, sendo a maioria pertencente à classe dos sesquiterpenos (71\%). Além disso, foi possível verificar que a fibra revestida com poliacrilato (PA) teve melhor desempenho, permitindo a extração de um maior número de compostos voláteis $(\mathrm{n}=35)$. As condições de extração que permitiram o isolamento de um maior número de compostos voláteis, corresponderam a tempos superiores de 26 min e temperaturas acima de $85^{\circ} \mathrm{C}$ com agitação de $79 \mathrm{rpm}$, isto para a fibra PA. Da mesma forma, verificou-se que os sesquiterpenos hidrocarbonetos foi a classe química mais presente nos frutos, o que está relacionado principalmente ao perfil volátil dos frutos de cambuí.

Palavras-chave: Cambuí. Myrtaceae. Microextração em fase sólida.

DOI: $10.5935 / 1806-6690.20210031$

Editor-in-Article: Prof. Alek Sandro Dutra - alekdutra@ufc.br

*Author for correspondence

Received for publication 24/02/2020; approved on 30/09/2020

${ }^{1}$ Work extracted from the thesis of the first author, presented to the Graduate Program in Agronomy, Federal University of Alagoas/UFAL-AL

${ }^{2}$ Graduate Program in Agronomy-Plant Production, Center for Agricultural Sciences, Federal University of Alagoas, Maceió-AL, Brazil; jenny_thesiba@ hotmail.com (ORCID ID 0000-0002-8833-259X), eurico@ceca.ufal. br (ORCID ID 0000-0002-0299-5676)

${ }^{3}$ Department of Chemistry, Federal University of Minas Gerais, Belo Horizonte-MG, Brazil; augusti.rodinei@gmail.com (ORCID ID 0000-0002-9448-9518)

${ }^{4}$ Department of Exact and Biological Sciences, Federal University of São João Del-Rei, Campus Sete Lagoas, Sete Lagoas-MG, Brazil; onesiomelo@gmail.com (ORCID ID 0000-0002-7483-0942) 


\section{INTRODUCTION}

Among the many native species in Brazil, the Myrtaceae family stands out as one of the most important in neotropics; many phytosociological studies regard the family as having the highest species richness (SILVA; MAZINE, 2016).

The Myrtaceae family is found throughout the world, but is best adapted to tropical and subtropical climates (SOUZA; LORENZI, 2005). This family is most often found in Brazilian biomes, with 23 genera and 1,034 species, ranking eighth in diversity in the Northeast region (SOBRAL et al., 2015; SOBRAL; PROENÇA, 2006; STADNIK; OLIVEIRA; ROQUE, 2016).

Many of these species have a high economic value, as is the case with eucalyptus (Eucalyptus spp.), which is used in the production of wood and the production of aromas; and guava (Psidium guajava), appreciated mainly for the characteristics of its fruits, which can be consumed in nature or industrialized (CARVALHO et al., 2014).

Some other species in this family also produce fleshy fruits widely appreciated for being edible. However, few are exploited on a commercial scale; and, when exploited, production is very small and limited to certain regions, such as araçá (Psidium cattleianum), cagaita (Eugenia dysenterica), cambucá (Plinia edulis (Vell.), Cambuci (Campomanesia phaea), cambuí (Myrciaria floribunda), guabiroba (Campomanesia xanthocarpa), grumixama (Eugenia brasiliensis Lam.), Jabuticaba (Myrciaria spp. O. Berg), jambolão (Syzygium cumini), pitanga (Eugenia uniflora 1. Cambess grape.) and the Cerrado pear (Eugenia klotzchiana) (BUENO et al., 2017; GUEDES et al., 2017; LORENZI et al., 2006).

Rumberry (Myrciaria floribunda), popularly known as "camboim," "jabuticabinha", "myrtle", "duke", "goiabarana" and "araçazeiro", is found across South America and Central America; in Brazil, it is found in an area ranging from Amazonia to the south of the country (LOZENZI et al., 2009; SOUZA; MORIM, 2008).

Rumberry is widely cultivated for its edible fruits, which have unique organoleptic characteristics, due to their high content of vitamin C and antioxidant action (PINHEIRO; ALMEIDA; SILVA, 2011; SILVA et al., 2012). They are relevant in the chemical composition of the essential oils of leaves, flowers and stems, in addition to being rich in phenolic compounds and having excellent biological functions, including antimicrobial, anticholinesterase, antioxidant, antitumor and insecticide (APEL et al., 2006; RAMOS et al., 2010; TIETBOHL et al., 2014).

Fruits are interesting for the fruit market, not only because of the technological potential they may have, but also because they can contribute to the diversification of the local cultivation of fruits, introducing new options for aromas and flavors to the market (MÜLLER et al., 2012).

The aroma, one of the most appreciated characteristics of fruits, consists of a complex mixture of volatile compounds belonging to various chemical classes (esters, acids, ketones, aldehydes, alcohols and terpenes), present in different concentrations and intensities, and are generally specific both for each species and for each variety (SINESIO et al., 2010; UEKANE; ROCHA-LEÃO; REZENDE, 2013).

The taste of fruits depends mainly on the perception of the mouth (sweetness, acidity or bitterness), as well as the smell produced by several of these volatile compounds, which determine the perception and acceptability of the products by consumers (EL HADI, 2013).

Given the above, there is a need to explore the chemical composition of rumberry fruits, so our objective was to optimize a method to determine the volatile profile of rumberry fruits, evaluating different extraction parameters (time, temperature and agitation) by solidphase microextraction in mode headspace.

\section{MATERIAL AND METHODS}

\section{Vegetal material}

The rumberry fruits of a single access (AC132) of those available in the Active Germplasm Bank of Rumberry (BAG - Rumberry) were collected manually, stored in polyethylene bags and transported to the Laboratory of Plant Biotechnology in the Center for Agricultural Sciences at the Federal University of Alagoas (CECA/UFAL), located in the municipality of Rio Largo - AL (09" 28 ' 42 "S and $35^{\circ} 51$ ' 12 " W) with an altitude of $127 \mathrm{~m}$.

Approximately $250 \mathrm{~g}$ of rumberry fruits were washed and disinfected with $20 \mathrm{~mL}$ of sodium hypochlorite solution (200 ppm) for 5 minutes with water movement, followed by a second rinse with running water for 2 minutes. Then, the fruits were crushed with the help of a mixer, discarding only the seeds, and the pulp obtained was stored in a freezer at $-60{ }^{\circ} \mathrm{C}$ until the time of analysis.

\section{Extraction of volatile compounds}

The frozen samples were transported to the Mass Spectrometry Laboratory of the Department of Chemistry at the Federal University of Minas Gerais (UFMG). For the extraction of volatile compounds, the polyacrylate (PA) polar fiber $(85 \mu \mathrm{m})$ and the divinylbenzene/carboxyne/polydimethylsiloxane (DVB/CAR/PDMS) semi-polar fiber $(50 / 30 \mu \mathrm{m})$ were used, using the solid-phase-headspace microextraction method (SPME-HS). 
We weighed $0.5 \mathrm{~g}$ of pulp from rumberry and put it in bottles with a capacity of $20 \mathrm{~mL}$, which were closed with an aluminum sell and a rubber septum (GARCÍA et al., 2019), to optimize the conditions of extraction of volatile organic compounds (VOC). The matrices were subjected to the experimental conditions established in the experimental design.

\section{Experimental planning}

The central composite design (CCD) was used, consisting of a factorial system $2^{3}$ (three factors on two levels), with 5 central points and 6 axial points, totaling 19 tests. The independent variables were extraction time, adsorption temperature and agitation, as shown in Table 1. Statistical analyses were performed using the software Statistica v.10 (Stat-Soft Inc., Tulsa, USA) (STATSOFT, 2011).

\section{Gas chromatography coupled to mass spectrometry}

The analysis of VOCs was carried out by means of a gas chromatograph (Trace GC Ultra) coupled to mass spectrometry (Polaris Q) (GC-MS), with an "ion trap" analyzer (Thermo Scientific, San José, CAUSE.). The separation was carried out on an HP-5 MS capillary column (5\% phenyl and 95\% methylpolysiloxane), $30 \mathrm{~m}$ wide, $0.25 \mathrm{~mm}$ internal diameter, $0.25 \mu \mathrm{m}$ film thickness and helium as a carrier gas, with a constant flow of $1 \mathrm{~mL}$ per minute. 1 (Agilent Techonolgies Inc, Germany). The injector temperature was $250{ }^{\circ} \mathrm{C}$ in splitless mode, with a time of 5 minutes; the temperature of the ion source was $200{ }^{\circ} \mathrm{C}$ and the temperature of the interface was $270{ }^{\circ} \mathrm{C}$. If you use the next hourly schedule: start at $40{ }^{\circ} \mathrm{C}$, stay 5 minutes at a heating speed of $2.5^{\circ} \mathrm{C}$ min- 1 to $125^{\circ} \mathrm{C}$ and temperature from $10{ }^{\circ} \mathrm{C} \mathrm{min}-1$ to $245^{\circ} \mathrm{C}$; for the temperature thereafter, keep the isotherm for 3 minutes (GARCÍA et al., 2019).

For the identification of VOCs, the retention indices of each peak of the chromatogram were compared with the mass spectra obtained by electron impact ionization (EI) at $70 \mathrm{eV}$, and the fullscan scanning range from 50 to $300 \mathrm{~m} / \mathrm{z}$. The peaks of the chromatogram that had an area greater than $0.15 \%$ and a similarity level (RSI) greater than 500 were considered, which

Table 1 - Variables used in factorial design $2^{3}$ with central component for the optimization of the HS-SPME conditions of the volatile substances from rumberry

\begin{tabular}{lccc}
\hline \multirow{2}{*}{ Variables } & \multicolumn{3}{c}{ Levels of variation } \\
\cline { 2 - 4 } & -1 & 0 & +1 \\
\hline Extraction time (min) & 10 & 20 & 30 \\
Adsorption temperature $\left({ }^{\circ} \mathrm{C}\right)$ & 30 & 65 & 100 \\
Agitation $(\mathrm{rpm})$ & 0 & 50 & 100 \\
\hline
\end{tabular}

were compared with the data obtained by the NIST library (National Institute of Standards and Technology). Peak areas were obtained from the Xcalibur 1.4 program from Thermo Electron Corporation (Thermo Electron, San Jose, CA, USA.), and transferred to Microsoft Excel 2013 (GARCÍA et al., 2016, 2019).

\section{RESULTS AND DISCUSSION}

To determine the ideal conditions for the extraction of VOCs for HS-SPME, the optimization of the factorial system $2^{3}$ was carried out, thus evaluating the effect of agitation, temperature, and extraction time for each of the tested fibers.

The solid-phase microextraction fibers (SPME), PA (polar) and DVB/CAR/PDMS (semipolar) were evaluated and compared individually according to the sum of the peak areas obtained in the chromatograms of the 19 tests, in such a way that a central composite design (CCD) was applied.

Table 2 shows the relative areas (\%) of the volatile compounds isolated for each of the SPME fibers. It is observed that the fiber with polyacrylate (PA) coating had better efficiency having the largest chromatographic area when the rumberry samples were submitted to $85^{\circ} \mathrm{C}$ and $79 \mathrm{rpm}$ of agitation for 26 minutes.

Studies by Silva et al. (2019), in which they evaluated five types of SPME fibers (PA, CAR/PDMS, PDMS/DVB, DVB/CAR/PDMS and CW/DVB) showed that the PA fiber was the most effective when submitting the cagaita samples to $45^{\circ} \mathrm{C}$, with agitation of $50 \mathrm{rpm}$ for 30 minutes. On the other hand, in García et al. (2019), where they optimized a methodology by HS-SPME-GC-MS for the study of VOCs from Acerola, reported better results when exposing the PA fiber to temperatures above $65^{\circ} \mathrm{C}$ for 20 minutes.

With the above, the efficiency of SPME fibers for the extraction of volatiles in fruits belonging to the Myrtaceae family is demonstrated. However, none of these studies reported the extraction and identification of volatile substances in fruits of rumberry.

Thus, Pareto plots (Figure 1) were generated with a $95 \%$ confidence limit, which show the influence of independent variables on the response variable, as well as their respective interactions.

Note that the independent variables, extraction time and temperature, showed a significant effect only for the PA fiber. An increase in these two variables allowed for greater extraction and, consequently, the identification of a greater number of volatile compounds. 
Table $2-2^{3}$ factorial design matrix and CCD in response to the sum of the chromatographic peaks obtained for each fiber by the HS-SPME-GC-MS method

\begin{tabular}{lccccc}
\hline \multirow{2}{*}{ Assay } & \multicolumn{3}{c}{ Factors } & \multicolumn{2}{c}{ Response Variables } \\
\cline { 2 - 5 } & Time (min) & Temperature $\left({ }^{\circ} \mathrm{C}\right)$ & Agitation (rpm) & PA (\%) & DVB/CAR/PDMS (\%) \\
\hline 1 & 14 & 45 & 21 & 130660658 & 5712883,925 \\
2 & 26 & 45 & 21 & 197421957 & 7884439,133 \\
3 & 14 & 85 & 21 & 171669590 & 18991038 \\
4 & 26 & 85 & 21 & 473628360 & 14316985,9 \\
5 & 14 & 45 & 79 & 72949751 & 23487624,8 \\
6 & 26 & 45 & 79 & 137765497 & 14074138,76 \\
7 & 14 & 85 & 79 & 318966807 & 23841402,9 \\
8 & 26 & 85 & 79 & 540193684 & 17013588,8 \\
9 & 10 & 65 & 50 & 85949619 & 2763265,76 \\
10 & 30 & 65 & 50 & 124736784 & 15844343 \\
11 & 20 & 30 & 50 & 76694399 & 8766278,08 \\
12 & 20 & 100 & 50 & 415749747 & 8365294,01 \\
13 & 20 & 65 & 0 & 155937458 & 165076,265 \\
14 & 20 & 65 & 100 & 174558957 & 20028526,6 \\
$15 *$ & 20 & 65 & 50 & 130723212 & 2107432,83 \\
$16 *$ & 20 & 65 & 50 & 116735828 & 9760817,99 \\
$17 *$ & 20 & 65 & 50 & 91195137 & 1145328,51 \\
$18^{*}$ & 20 & 65 & 50 & 106424019 & 3496468,34 \\
$19 *$ & 20 & 65 & 50 & 105421098 & 3797181,45 \\
\hline
\end{tabular}

SPME fibers: divinylbenzene/carboxen/polydimethylsiloxane (DVB/CAR/PDMS) and polyacrylate (PA). * Central points

Figure 1 - Pareto graph of the PA (a) and DVB/CAR/PDMS (b) fibers, in relation to the partial area of the analyzed chromatograms of the fruits of rumberry
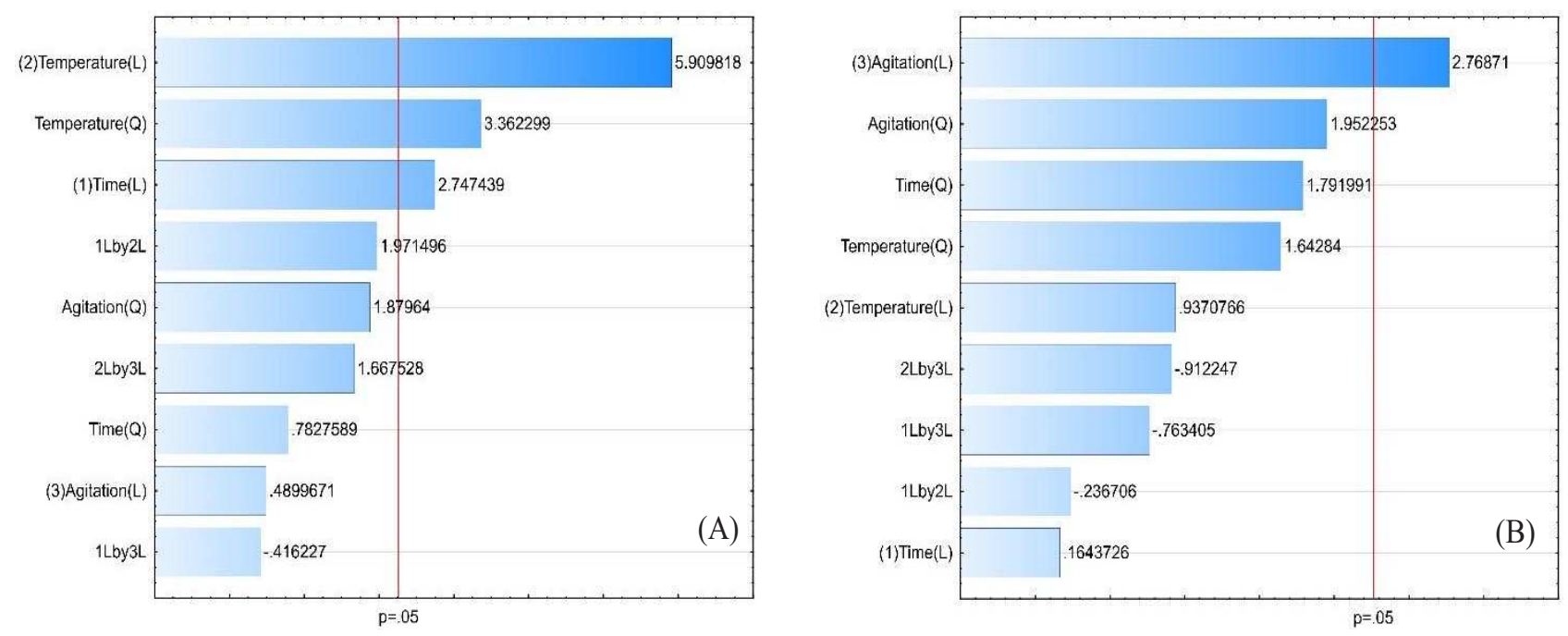
However, only one independent variable (agitation) showed an influence on the extraction of volatile compounds directly with a positive effect for the DVB/CAR/PDMS fiber, which presented a linear model (indicated by the letter L). The other factors had no significant effect, for a level of $5 \%$ of significance.

The effects of the significant variables for both fibers are shown in Figure 2. It is noted in Figures 2 (a) and 2 (c) that the longer the extraction time and temperature (time $>20$ minutes and temperature $>90^{\circ} \mathrm{C}$ ), the greater the number of identified VOCs. Thus, the best extraction combination is obtained at 26 minutes at $85^{\circ} \mathrm{C}$ and 79 $\mathrm{rpm}$, which refers to assay no. 8 , since it was the one that obtained the highest value in the sum of the areas of the chromatographic peaks (Table 2).

Figures 2 (b) and 2 (d) show that, at higher revolutions per minute (agitation $>60^{\circ} \mathrm{C}$ ) and high temperature values, better results are obtained in the extraction of volatile compounds, which refers to assay no. 7 (Table 2).
Thus, comparing both fibers, it was found that the extraction time was an important factor in the extraction of VOCs from the fruits of rumberry, as shown in assays 7 and 8 of Table 2; and the fiber DVB/CAR/PDMS, when exposed for shorter times ( $<14$ minutes) extracted fewer VOCs compared to PA fiber, which required longer times ( $>25$ minutes) to isolate a greater number of VOCs.

This result shows that the use of higher temperatures, times or agitations will not always allow the detection of a greater number of volatile substances, as these parameters are influenced according to the type of fiber used.

Once the extraction conditions were determined, the analysis of the volatile compounds present in the rumberry samples was carried out. We identified 48 compounds belonging to different chemical classes, with sesquiterpene hydrocarbons being the most abundant (54\%), followed by oxygenated monoterpenes (19\%), oxygenated sesquiterpenes $(17 \%)$ and monoterpene hydrocarbons (10\%) (Table 3).

Figure 2 - Response surfaces and contour curves obtained from the CCD for the variables of temperature and time of extraction through Fiber PA $(a, c)$ and temperature of extraction and agitation through Fiber DVB/CAR/PDMS (b, d)

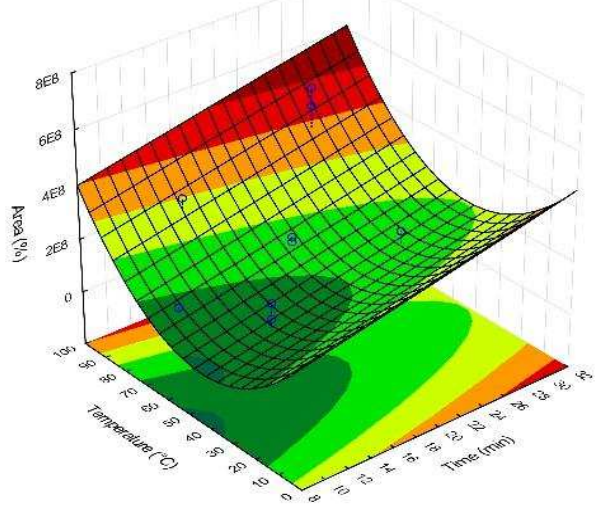

(A)
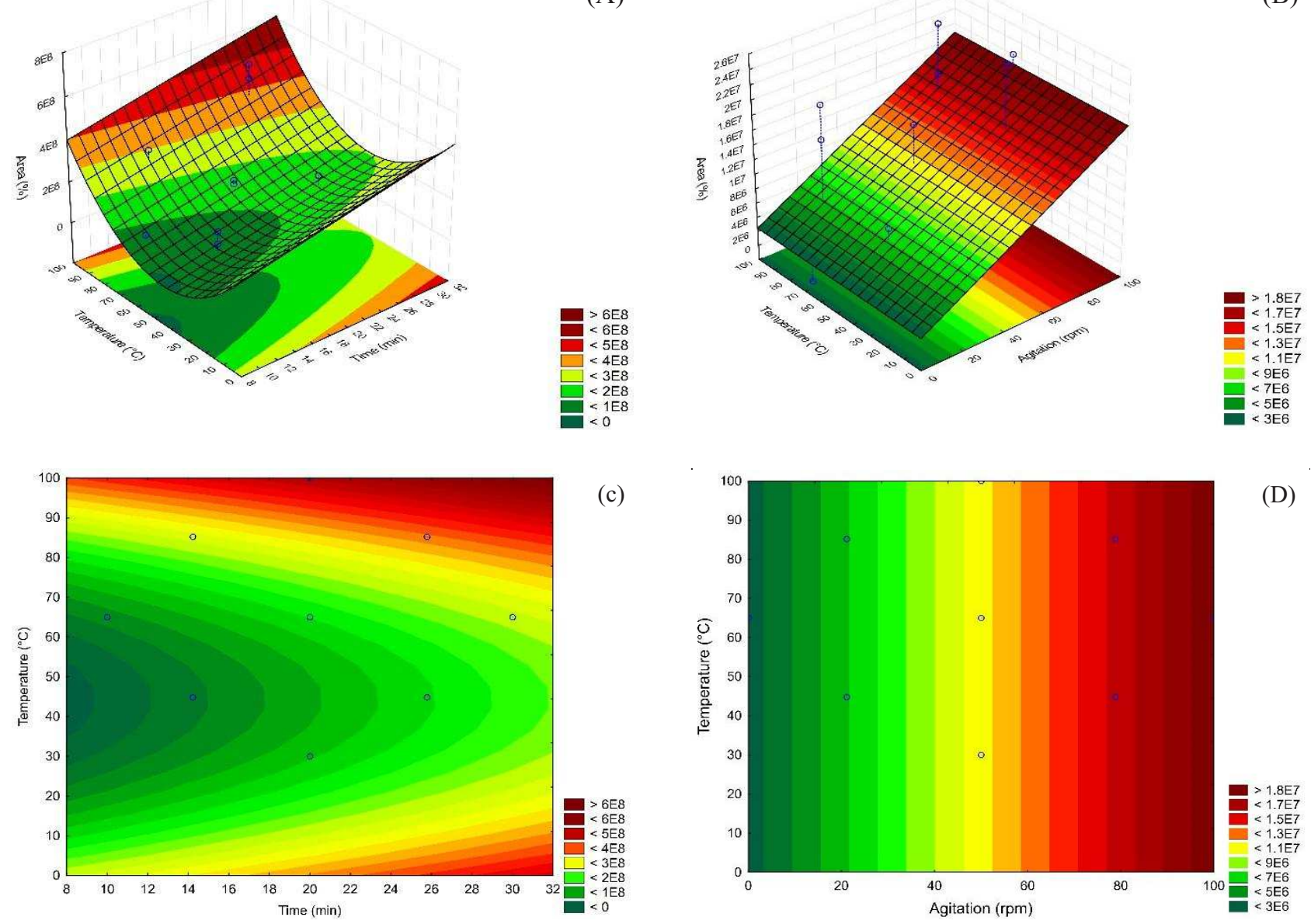
Table 3 - Volatile compounds detected in rumberry fruits, using HS-SPME/GC-MS

\begin{tabular}{|c|c|c|c|c|c|c|}
\hline \multirow{2}{*}{$\mathrm{N}^{\mathrm{o}}$. } & \multirow{2}{*}{ Classification } & \multirow{2}{*}{ COVsa } & \multirow{2}{*}{ Formula } & \multirow{2}{*}{ CAS } & \multicolumn{2}{|r|}{ SPME fibers } \\
\hline & & & & & $\mathrm{PA}$ & DVB/CAR/PDMS \\
\hline 1. & \multirow{9}{*}{ Oxygenated monoterpenes } & Sabinene hydrate & $\mathrm{C}_{10} \mathrm{H}_{18} \mathrm{O}$ & $15537-55-0$ & & $\mathrm{X}$ \\
\hline 2. & & endo-Keto Borneol & $\mathrm{C}_{10} \mathrm{H}_{16} \mathrm{O}_{2}$ & $114529-11-2$ & $\mathrm{x}$ & \\
\hline 3. & & 6-Camphenol & $\mathrm{C}_{10} \mathrm{H}_{16} \mathrm{O}$ & $55925-49-0$ & & $\mathrm{X}$ \\
\hline 4. & & cis-Crisantenol & $\mathrm{C}_{10} \mathrm{H}_{16} \mathrm{O}$ & $55722-60-6$ & & $\mathrm{X}$ \\
\hline 5. & & Dihydrocarbyl acetate & $\mathrm{C}_{12} \mathrm{H}_{20} \mathrm{O}_{2}$ & $20777-49-5$ & $\mathrm{x}$ & \\
\hline 6. & & Eucalyptus & $\mathrm{C}_{10} \mathrm{H}_{18} \mathrm{O}$ & $470-82-6$ & & $\mathrm{X}$ \\
\hline 7. & & cis-p-Mentha-2,8-dien-1-ol & $\mathrm{C}_{10} \mathrm{H}_{16} \mathrm{O}$ & $22771-44-4$ & & $\mathrm{X}$ \\
\hline 8. & & Linalyl propionate & $\mathrm{C}_{13} \mathrm{H}_{22} \mathrm{O}_{2}$ & $144-39-8$ & $\mathrm{x}$ & \\
\hline 9. & & $\alpha$-campholenaldehyde & $\mathrm{C}_{10} \mathrm{H}_{16} \mathrm{O}$ & $4501-58-0$ & $\mathrm{x}$ & \\
\hline 10. & \multirow{5}{*}{ Monoterpene hydrocarbons } & Carene & $\mathrm{C}_{10} \mathrm{H}_{16}$ & $13466-78-9$ & $\mathrm{x}$ & $\mathrm{X}$ \\
\hline 11. & & Sylvestrene & $\mathrm{C}_{10} \mathrm{H}_{16}$ & $1461-27-4$ & $\mathrm{x}$ & \\
\hline 12. & & $\alpha$-Fenchene & $\mathrm{C}_{10} \mathrm{H}_{16}$ & $7378-37-2$ & $\mathrm{x}$ & \\
\hline 13. & & $\alpha$-Pinene ${ }^{1,3}$ & $\mathrm{C}_{10} \mathrm{H}_{16}$ & $2437-95-8$ & $\mathrm{x}$ & $\mathrm{X}$ \\
\hline 14. & & $\beta$-Terpinene ${ }^{2}$ & $\mathrm{C}_{10} \mathrm{H}_{16}$ & 99-84-3 & $\mathrm{x}$ & \\
\hline 15. & \multirow{8}{*}{ Oxygenated sesquiterpenes } & Agarospirol & $\mathrm{C}_{15} \mathrm{H}_{26} \mathrm{O}$ & $23811-08-7$ & $\mathrm{x}$ & \\
\hline 16. & & Carotol & $\mathrm{C}_{15} \mathrm{H}_{26} \mathrm{O}$ & $465-28-1$ & $\mathrm{x}$ & \\
\hline 17. & & Cubebol & $\mathrm{C}_{15} \mathrm{H}_{26} \mathrm{O}$ & $23445-02-5$ & $\mathrm{x}$ & $\mathrm{X}$ \\
\hline 18. & & Globulol $^{2}$ & $\mathrm{C}_{15} \mathrm{H}_{26} \mathrm{O}$ & $489-41-8$ & & $\mathrm{X}$ \\
\hline 19. & & Guaiol & $\mathrm{C}_{15} \mathrm{H}_{26} \mathrm{O}$ & $489-86-1$ & $\mathrm{x}$ & \\
\hline 20. & & Terpinen-4-ol acetate & $\mathrm{C}_{12} \mathrm{H}_{20} \mathrm{O}_{2}$ & $4821-04-9$ & $\mathrm{x}$ & \\
\hline 21. & & Viridiflorol & $\mathrm{C}_{15} \mathrm{H}_{24} \mathrm{O}$ & $21747-46-6$ & $\mathrm{x}$ & $\mathrm{X}$ \\
\hline 22. & & $\gamma$-Eudesmol ${ }^{2}$ & $\mathrm{C}_{15} \mathrm{H}_{26} \mathrm{O}$ & 1209-71-8 & $\mathrm{x}$ & \\
\hline 23. & \multirow{19}{*}{ Sesquiterpene hydrocarbons } & Aromadendene & $\mathrm{C}_{15} \mathrm{H}_{24}$ & 109119-91-7 & & $\mathrm{X}$ \\
\hline 24. & & Allo-aromadendene ${ }^{2}$ & $\mathrm{C}_{15} \mathrm{H}_{24}$ & $25246-27-9$ & & $\mathrm{X}$ \\
\hline 25. & & Cadina-1 (10), 4-diene & $\mathrm{C}_{15} \mathrm{H}_{24}$ & $16729-01-4$ & $\mathrm{x}$ & \\
\hline 26. & & Caryophyllene & $\mathrm{C}_{15} \mathrm{H}_{24}$ & $13877-93-5$ & $\mathrm{x}$ & $\mathrm{X}$ \\
\hline 27. & & Cyperene & $\mathrm{C}_{15} \mathrm{H}_{24}$ & $2387-78-2$ & $\mathrm{x}$ & \\
\hline 28. & & Epizonarene & $\mathrm{C}_{15} \mathrm{H}_{24}$ & $5975-30-4$ & $\mathrm{x}$ & \\
\hline 29. & & Germacrene D & $\mathrm{C}_{15} \mathrm{H}_{24}$ & $37839-63-7$ & & $\mathrm{X}$ \\
\hline 30. & & Longifolene & $\mathrm{C}_{15} \mathrm{H}_{24}$ & $475-20-7$ & $\mathrm{x}$ & \\
\hline 31. & & Patchoulene & $\mathrm{C}_{15} \mathrm{H}_{24}$ & $1405-16-9$ & $\mathrm{x}$ & \\
\hline 32. & & Presilphiperfol-7-ene & $\mathrm{C}_{15} \mathrm{H}_{24}$ & $80931-09-5$ & $\mathrm{x}$ & \\
\hline 33. & & Sativene & $\mathrm{C}_{15} \mathrm{H}_{24}$ & $3650-28-0$ & $\mathrm{x}$ & \\
\hline 34. & & Valencene $^{1}$ & $\mathrm{C}_{15} \mathrm{H}_{24}$ & $4630-07-3$ & $\mathrm{x}$ & \\
\hline 35. & & $\alpha$-Cubebene & $\mathrm{C}_{15} \mathrm{H}_{24}$ & $17699-14-8$ & $\mathrm{x}$ & $\mathrm{X}$ \\
\hline 36. & & $\alpha$-Guaiene ${ }^{3}$ & $\mathrm{C}_{15} \mathrm{H}_{24}$ & $53863-54-0$ & $\mathrm{x}$ & $\mathrm{X}$ \\
\hline 37. & & $\alpha$-Gurjunene ${ }^{2}$ & $\mathrm{C}_{15} \mathrm{H}_{24}$ & $489-40-7$ & & $\mathrm{X}$ \\
\hline 38. & & $\alpha$-Muurolene & $\mathrm{C}_{15} \mathrm{H}_{24}$ & 10208-80-7 & & $\mathrm{X}$ \\
\hline 39. & & $\alpha$-Copaene & $\mathrm{C}_{15} \mathrm{H}_{24}$ & $3856-25-5$ & & $\mathrm{X}$ \\
\hline 40. & & Calarene & $\mathrm{C}_{15} \mathrm{H}_{24}$ & $17334-55-3$ & $\mathrm{x}$ & \\
\hline 41. & & $\beta$-Selinene $\mathrm{e}^{1,2,3}$ & $\mathrm{C}_{15} \mathrm{H}_{24}$ & $17066-67-0$ & $\mathrm{x}$ & $\mathrm{X}$ \\
\hline
\end{tabular}


Continuation table 3

\begin{tabular}{|c|c|c|c|c|c|}
\hline 42. & $\gamma$-Cadinene ${ }^{2}$ & $\mathrm{C}_{15} \mathrm{H}_{24}$ & $5957-55-1$ & $\mathrm{x}$ & $\mathrm{X}$ \\
\hline 43. & $\gamma$-Elemene & $\mathrm{C}_{15} \mathrm{H}_{24}$ & $370572-92-2$ & $\mathrm{x}$ & \\
\hline 44. & $\gamma$-Gurjunene & $\mathrm{C}_{15} \mathrm{H}_{24}$ & $22567-17-5$ & $\mathrm{x}$ & $\mathrm{X}$ \\
\hline 45. & $\gamma$-Muurolene ${ }^{2}$ & $\mathrm{C}_{15} \mathrm{H}_{24}$ & 24268-39-1 & $\mathrm{x}$ & $\mathrm{X}$ \\
\hline 46. & $\gamma$-Himachalene ${ }^{1}$ & $\mathrm{C}_{15} \mathrm{H}_{24}$ & $53111-25-4$ & $\mathrm{x}$ & $\mathrm{X}$ \\
\hline 47. & $\delta$-Cadinene ${ }^{2}$ & $\mathrm{C}_{15} \mathrm{H}_{24}$ & $483-76-1$ & $\mathrm{x}$ & $\mathrm{X}$ \\
\hline 48. & $\delta$-Selinene & $\mathrm{C}_{15} \mathrm{H}_{24}$ & $28624-23-9$ & & $\mathrm{X}$ \\
\hline
\end{tabular}

${ }^{a}$ Compounds identified by comparing their mass spectra and retention indices according to the NIST library (2007); SPME fibers: divinylbenzene/ carboxen/polydimethylsiloxane (DVB/CAR/PDMS) and polyacrylate (PA); compounds identified by other authors in different parts of the $M$. floribunda plant: ${ }^{1}$ Oliveira et al. (2018), (lyophilized fruits); ${ }^{2}$ Ramos et al. (2010) (fresh leaves); ${ }^{3}$ Tietbohl et al. (2012), (leaves, stems and flowers); CAS: unique numerical identifier for chemical compounds

These results are similar to those obtained in fruits such as Campomanesia adamantium (Gabiroba), Eugenia dysenterica (cagaita) and Myrciaria dubia (camu-camu), in which the volatile composition is mainly represented by the chemical group of sesquiterpenes (OLIVEIRA et al., 2016; SILVA et al., 2019).

Some volatile compounds found in the present study have already been previously identified by other authors, among which are $\alpha$-pinene, $\beta$-terpinene, globulol, $\gamma$-eudesmol, Valencian, $\alpha$-guaiene, $\alpha$-gurjunen, $\beta$-selinen, cadinene and himachalene (OLIVEIRA et al., 2018; RAMOS et al., 2010; TIETBOHL et al., 2012). However, a large part of these compounds had not yet been identified in rumberry pulp.

Of the compounds detected, 13 were similar between both fibers, the most representative being carene, caryophyllene, cubebol, viridiflorene, $\alpha$ cubebene, and $\gamma$-gurjunene because there are no reports in the literature on these compounds.

Most of the volatile substances identified in the present study corresponded to the class of hydrocarbon sesquiterpenes. These results corroborate studies carried out on the chemical composition of the volatile oil of four species of Mirtaceae, in which the presence of the groups cariolifeno, aromadendreno and germacreno were detected (APEL et al., 2006).

On the contrary, studies by Mehta et al. (2018), where they determined the VOCs of jambolan (Syzygium cumini L.) fruits in three maturation stages, concluded that the main compounds that grant the aromatic characteristics to the fruit were karyophylene, $\delta$-cadinene and $\alpha$-fenchene.

Ramos et al. (2010) and Tietbohl et al. (2012, 2014), when isolating the essential oil from different parts of the M. floribunda plant (leaves, stems and flowers), mentioned the class of monoterpenes and sesquiterpenes as the most important components. Similarly, the group of hydrocarbon sesquiterpenes (40.6\%) was found in greater amounts in lyophilized fruits of rumberry, of which (through the CAR/DVB/PDMS fiber) $\alpha$-pinene, longicycline and $\alpha$-humulene were also reported in the present study (OLIVEIRA et al., 2018).

\section{CONCLUSIONS}

1. The application of the HS-SPME-GC-MS method proved to be satisfactory for the extraction of VOCs from rumberry fruits;

2. The methodology used to evaluate the efficiency of the fibers showed that the PA fiber is the most suitable for the extraction of VOCs from rumberry fruits, since it extracted a greater number of compounds;

3.It was also found that the technique is effective and adequate at temperatures above $85{ }^{\circ} \mathrm{C}$ for 26 minutes and $79 \mathrm{rpm}$, thus extracting compounds belonging mainly to the class of sesquiterpenic hydrocarbons, such as $\delta$-cadinene, $\gamma$-himachalene, $\gamma$-muurolene, $\gamma$ gurjunen, $\gamma$-cadinene, $\beta$-selene, $\alpha$-guaiene, $\alpha$-cubebene and caryophyllene, which were detected by both fibers.

\section{ACKNOWLEDGEMENTS}

The authors wish to thank CAPES and FAPEAL for their financial support.

\section{REFERENCES}

APEL, M. A. et al. Screening of the biological activity from essential oils of native species from the Atlantic rain forest (São Paulo-Brazil). Pharmacologyonline, v. 3, p. 376-383, 2006. 
BUENO, G. H. et al. Caracterização física e físico-química de frutos de Eugenia dysenterica DC. originados em região de clima tropical de altitude. Revista Brasileira de Biometria, v. 35, n. 3, p. 515-522, 2017.

CARVALHO, J. et al. Constituintes químicos e atividade antioxidante de folhas e galhos de Eugenia copacabanensis Kiaersk (Myrtaceae). Química Nova, v. 37, n. 3, p. 477-482, 2014.

EL HADI, M. A. et al. Advances in fruit aroma volatile research. Molecules, v. 18, n. 7, p. 8200-8229, 2013.

GARCÍA, Y. M. et al. SPME fiber evaluation for volatile organic compounds extraction from acerola. Journal of the Brazilian Chemical Society, v. 30, n. 2, p. 247-255, 2019.

GARCÍA, Y. M. et al. Volatile compounds identified in Barbados Cherry 'BRS-366 Jaburú.' Scientific Electronic Archives, v. 3, p. 67-73, 2016.

GUEDES, M. N. S. et al. Minerals and phenolic compounds of cagaita fruits at different maturation stages (Eugenia dysenterica). Revista Brasileira de Fruticultura, v. 39, n. 1, 2017.

LORENZI, H. Árvores brasileiras: manual de identificação e cultivo de plantas arbóreas nativas do Brasil, São Paulo: Nova Odessa - Instituto Plantarum de Estudo da Flora, v. 3, p. 384,2009

MEHTA, P. K. et al. Volatile constituents of Jambolan (Syzygium cumini L.) fruits at three maturation stages and optimization of HS-SPME GC-MS method using a central composite design. Food Analytical Methods, v.11, n. 3, p. 733-749, 2018.

MÜLLER, N. T. G. et al. Análise fitoquímica das folhas de myrtaceae: Psidium cattleianum Sabine E Campomanesia guazumaefolia (CAMB.) Berg. Revista Eletrônica de Extensão da URI, v. 8, n. 14, p. 65-71, 2012.

OLIVEIRA, J. D. et al. Rendimento, composição química e atividades antimicrobiana e antioxidante do óleo essencial de folhas de Campomanesia adamantium submetidas a diferentes métodos de secagem. Revista Brasileira de Plantas Medicinais, v. 18, n. 2, p. 502-510, 2016.

OLIVEIRA, L. M. de et al. Chemical characterization of Myrciaria floribunda (H. West ex Willd) fruit. Food Chemistry, v. 248, p. 247-252, 2018.

PINHEIRO, L. R.; ALMEIDA, C. S.; SILVA, A. V. C. Diversidade genética de uma população natural de cambuizeiro e avaliação pós-colheita de seus frutos. Scientia Plena, v. 7, n. 6, p. 1-5, 2011.

RAMOS, M. F. D. S. et al. Essential oils from Myrtaceae species of the Brazilian Southeastern maritime forest (Restinga). Journal of Essential Oil Research, v. 22, n. 2, p. 109-113, 2010.
SILVA, A. T. da; MAZINE, F. F. A família Myrtaceae na Floresta Nacional de Ipanema, Iperó, SP. Rodriguésia, v. 67, n. 1, p. 203-224, 2016.

SILVA, A. V. C. et al. Biometria de frutos e sementes de cambuí (Myciaria tenella O. Berg). Revista Agro@mbiente, v. 6, n. 3, p. 258-262, 2012.

SILVA, M. R. et al. Evaluation of the influence of extraction conditions on the isolation and identification of volatile compounds from cagaita (Eugenia dysenterica) using HSSPME/GC-MS. Journal of the Brazilian Chemical Society, v. 30, n. 2, p. 379-387, 2019.

SINESIO, F. et al. Perceptive maps of dishes varying in glutamate content with professional and naive subjects. Food Quality and Preference, v. 21, n. 8, p. 1034-1041, 2010.

SOBRAL, M. et al. Thirteen new Myrtaceae from Bahia, Brazil. Phytotaxa, v. 224, p. 201-231, 2015.

SOBRAL, M.; PROENÇA, C. E. B. Siphoneugena delicata (Myrtaceae), a new species from the Montane Atlantic Forests of Southeastern Brazil. Novon: A Journal for Botanical Nomenclature, v. 16, n. 4, p. 530-532, 2006.

SOUZA, M. da C.; MORIM, M. P. Subtribos Eugeniinae O. Berg e Myrtinae O. Berg (Myrtaceae) na Restinga da Marambaia, RJ, Brasil. Acta Botanica Brasilica, v. 22, n. 3, p. 652-683, 2008.

SOUZA, V. C.; LORENZI, H. Botânica sistemática: guia ilustrado para identificação das famílias de Angiospermas da flora brasileira, baseado em APG II. Nova Odessa, SP: Instituto Plantarum, 2005. 640 p.

STADNIK, A.; OLIVEIRA, M. I. U.; ROQUE, N. Levantamento florístico de Myrtaceae no município de Jacobina, Chapada Diamantina, BA. Hoehnea, v. 43, n. 1, p. 87-97, 2016.

STATSOFT. Statistica (Data analysis soft-ware system). version 10. Tulsa, OK: StatSoft, 2011.

TIETBOHL, L. A. C. et al. Avaliação laboratorial dos efeitos do óleo essencial de folhas de Myrciaria floribunda no desenvolvimento de Dysdercus peruvianus e Oncopeltus fasciatus. Revista Brasileira de Farmacognosia, v. 24, p. 316-321, 2014.

TIETBOHL, L. A. C. et al. Comparative study and anticholinesterasic evaluation of essential oils from leaves, stems and flowers of Myrciaria floribunda (H. West ex Willd.) O. Berg. Latin American Journal of Pharmacy, v. 31, n. 4, p. 637-641, 2012.

UEKANE, T. M.; ROCHA-LEÃO, M. H. M.; REZENDE, C. M. Compostos sulfurados no aroma do café: origem e degradação. Revista Virtual de Química, v. 5, n. 5, p. 891-911, 2013.G. 